\title{
Complications Related to Surgical Treatment of Intervertebral Disc Disease in Dogs
}

\author{
L. LEXMAULOVÁ, R. NOVOTNÁ, P. RAUŠER, A. NEČAS \\ Department of Surgery and Orthopaedics, Small Animal Clinic, University of Veterinary and Pharmaceutical \\ Sciences, Brno, Czech Republic
}

Received July 9, 2007

Accepted February 14, 2008

\begin{abstract}
Lexmaulová L., R. Novotná, P. Raušer, A. Nečas: Complications Related to Surgical Treatment of Intervertebral Disc Disease in Dogs. Acta Vet. Brno 2008, 77: 269-276.

After intervertebral disk surgery we often have to deal with various complications (seizures, gastrointestinal tract (GIT) ulcerations, cystitis, and surgical wound healing problems). These complications may lead to the death of the patient. We performed clinical and laboratory investigations in 161 dogs with an intervertebral disc disease. After that, we performed a cranial $(n=31)$, caudal $(n=125)$ or both $(n=5)$ types of myelography at the same time, and surgery - ventral slot decompression (SLOT) $(n=18)$ or hemilaminectomy $(n=143)$. During the postsurgical period we observed seizures, GIT complications, cystitis, and surgical wound healing problems or even death of the patients. These complications appeared to be related to the lesion site, the degree of clinical signs and the type of surgical procedure. In our study we found a higher incidence of seizures after cranial myelography, higher incidence of gastrointestinal (GI) complications particularly in paraplegic dogs, and a higher risk of death in patients after the SLOT surgery. The occurrence of cystitis was not significant ( $p=0.5524, p=0.1655$, respectively). We consider seizures, GI ulcerations, and death the most frequent complications after intervertebral disc surgery. Their incidence depends on the lesion site and the degree of neurologic symptoms.
\end{abstract}

Hemilaminectomy, seizures, gastrointestinal ulceration

For a surgical procedure to be successful, it is important not only to make an early and correct diagnosis and to perform decompression as soon as possible, but also to take proper care both before and after the surgery. Postponed surgery worsens prognosis for paraplegic patients, and there is usually a need for longer recovery (Nečas 1999, 2000). In such patients, the electrostimulation test is recommend to decide if there is any chance to succeed with surgery at all (Bauer et al. 1992).

During the post-surgery period we observed in patients with the intervertebral disc disease several complications (seizures, GI ulcerations, cystitis, pyelonephritis and surgical wound healing problems) that might lead to the death of the patients (Hart et al. 1997ab).

The occurrence of seizures during recovery from anaesthesia is thought to be related to myelography (Roberts and Selcer 1993). The frequency of seizures is affected by the type and volume of contrast medium, type of myelography, anaesthetics, weight, and hydration status of the patient (Barone et al. 2002; Roberts and Selcer 1993; Wright and Clayton 1981).

GI ulcerations usually lead to vomiting and/or bloody diarrhoea (fresh or digested). It is generally thought to be caused by using steroids in the perioperative period, particularly by dexamethasone (Hart et al. 1997b; Toombs et al. 1980). The risk of a deep ulcer and consequently, the occurrence of colon perforation increases with a slow faeces passage and with obstipation. An inflammatory response of the organism is reduced by steroids, thus soon after a clinical manifestation of colon perforation these animals die (Toombs et al. 1986).

The ability to urinate can be reduced in paraplegic patients (Oliver et al. 1987; Toombs

Address for correspondence:

MVDr. Leona Lexmaulová

Klinika chorob psủ a koček

Veterinární a farmaceutická univerzita Brno

Palackého 1/3, 61242 Brno

Phone: +420604270861

E-mail:rauseroval@vfu.cz

http://www.vfu.cz/acta-vet/actavet.htm 
and Bauer 1993). This might predispose the animals to urinary tract infections (Amsellem et al. 2003). If the lesion is localized cranially from L4, the tone of proximal urethra is increased (so called "upper motor neuron bladder syndrome") and urine cannot by easily squeezed out of the urinary bladder. If the lesion is localized more caudally (behind L4), urine can be easily squeezed out of the urinary bladder, because the tone of proximal urethra is decreased and urinary bladder is usually atonic (so called "lower motor neuron bladder syndrome") (Amsellem et al. 2003; Oliver et al. 1987). In paraplegic patients we usually do not observe signs of dysuria or pollakiuria; we only observe haematuria. Antibiotic treatment should be initiated after urine culture and known pathogen sensitivity (Hart et al. 1997a). Surgical wound healing problems may include oedema, bleeding, haematoma, seroma, infection and dehiscence. Oedema is the most common complication; however, it usually does not require any treatment. The risk of haemorrhage and haematoma of the surgical wound can be higher when non-steroidal anti-inflammatory drugs (NSAIDs) have been given. Seroma is not usually clinically significant and does not need any therapy; however, it is rich in protein and predisposed to infection, which is a serious but rare complication after spine surgery (Hart et al. 1997b). In recumbent patients there is always the risk of decubital ulcers and intertrigo (Hart et al. 1997b). These problems might be prevented by placing the patients on a clean absorbent pad. Thus, intertrigo in the anal, vulvar, and caudal thigh regions caused by irritation from faeces and urine can be avoided. As a preventive or therapeutic measure, it is possible to apply ointment on the anal and vulvar regions. It helps to maintain the animals' welfare (Oliver et al. 1987).

Death of the animal may be caused by a wide range of conditions. Depression, apnoea, and arrhythmias may occur while the contrast medium enters the subarachnoidal space (Harvey et al. 1996). If compared with thoracolumbar vertebral surgery, arrhythmias appear to be more frequent in cervical vertebral surgeries (Coates 2000). GI ulceration might progress into gut perforation, particularly in the colon. Consequently, septic peritonitis and sepsis may follow (Toombs et al. 1980, 1986).

The purpose of this study was to document all complications during the perioperative and postoperative time in patients with an intervertebral disc disease after the surgical procedure based on decompression. In addition, we tried to find whether the observed complications (seizures, GI complications, cystitis, bleeding and death) are related to the lesion site and the degree of neurological signs.

\section{Materials and Methods}

\section{Study animal group}

Between 2000 and 2002 we performed surgeries in 161 dogs with an intervertebral disc disease at our clinic (94 males and 67 females, aged $7.2 \pm 4.23$ years, weighing $10.7 \pm 6.75 \mathrm{~kg}$ ). All the patients were vaccinated and dewormed. Neurological examination was performed and the degree of clinical signs and localization of the lesions were determined. In 18 patients we found neurological deficits in thoracic limbs and in 143 dogs in pelvic limbs. According to the degree of clinical signs, the patients were divided into groups I - III when the cervical spine was affected (I - first episode of cervical pain, II - recurrent pain, III - pain with neurological deficit) and groups I - IV when thoracolumbar spine was affected (I - first episode of back pain, II - recurrent pain and/or mild to moderate paraparesis, III - severe paraparesis, IV - paraplegia) (Toombs and Bauer 1993). We performed blood chemistry and haematology examination in all patients.

Experimental procedure and design

After a physical and neurological examination we placed the intravenous catheter into the cephalic antebrachial vein or lateral saphena vein and collected a blood sample for routine blood tests (biochemistry and haematology), emptied the urinary bladder and performed a fast urinoanalysis using a screening test strip.

These patients were then sedated by intravenously administered medetomidin (Domitor inj., Pfizer, Belgium) at the dose of $0.02 \mathrm{mg} / \mathrm{kg}$ and buprenorfine (Temgesic inj., Reckitt and Colman, U.K.) at the dose of $0.01 \mathrm{mg} / \mathrm{kg}$ in one syringe. As induction to general anaesthesia we used propofol (Propofol Abbott inj., Abbott Lab., USA) at the dose of $1-2 \mathrm{mg} / \mathrm{kg}$. General anaesthesia was based on the application of oxygen and nitrous oxide $(1: 1)$ with isoflurane (Forane, Abbott Lab., USA) at the concentration of $0.5-1.5$ vol.\% (inhalation anaesthesia machine Anemat N8, Chirana, Czech Republic). We closely monitored the patient's heart and respiratory rate, end-tidal 
$\mathrm{CO}_{2}$ and haemoglobin saturation by oxygen (Datex Cardiocap II, Datex-Ohmeda, Finland). We also gave an infusion of the Ringer's lactate solution at the dose of $10 \mathrm{ml} / \mathrm{kg} / \mathrm{hr}$ during anaesthesia.

Based on the lesion localization by neurological examination we performed a cerebrospinal fluid (CSF) collection and myelography (Nečas and Sedláková 1999). Patients with CSF changes were excluded from the study. Iopamidol or iomeprol were used as a contrast medium. In patients with cervical spine lesion $(n=18)$ the contrast medium was given into cisterna magna (cranial myelography) in 16 of 18 dogs, and in 1 of 18 dogs into the subarachnoidal space between L4 and L5 (caudal myelography), and in 1 of 18 both cranial and caudal myelography were performed at the same time (Dennis 1987). In patients with thoracolumbar spine lesion $(n=143)$ the contrast medium was given into the subarachnoidal space between L4 and L5 in 124 dogs, cranial myelography was performed in 15 dogs, and in 4 dogs both cranial and caudal myelography were performed (Sande 1992). Radiography of the affected region was performed in all the patients using 4 projections.

Based on myelography, we performed the surgery - SLOT (ventral slot decompression) $(\mathrm{n}=18)$ when the lesion was localized in the cervical spine (Toombs and Bauer 1993) or hemilaminectomy $(n=143)$ when the lesion was localized in the thoracolumbar spine (Toombs and Bauer 1993). The surgery was performed by two specialists from the University, A. Nečas and M. Dvořák. During the perioperative time methylprednisolon sodium succinate was given at $30 \mathrm{mg} / \mathrm{kg}$ (Nečas 1999).

After the surgery we placed the dog in a quiet room on a slant, absorbant, non-slip pad with the patient's head placed up. We continued with the application of Ringer's lactate according to hydration status of the patient.

Within the next $12 \mathrm{~h}$ we observed seizures. We considered seizure as generalized muscle fasciculations. When we observed such signs, we started the application of diazepam (Apaurin inj., Krka, Slovenia) at the dose of $0.3 \mathrm{mg} / \mathrm{kg}$

We also monitored the patient's overall health condition: its behaviour, reactions, food and water intake, respiratory and heart rates, temperature, and we also evaluated mucous membranes. The monitoring was carried out three times a day for 10 days.

As for the GI complications, we noted conditions such as vomiting and/or diarrhoea with or without blood (fresh or digested).

In patients that did not urinate we manually emptied their urinary bladder four times a day. When the urine was squeezed out of the bladder we assessed the amount and quality of the urine (sensual evaluation and strip test). To measure the urine amount, we collected it into a dish. The diagnosis of urinary tract disease was based on the finding of proteinuria and haematuria, eventually on the finding of abnormal health condition. When general health condition appeared to be abnormal, we examined the biochemistry blood profile, laboratory urinoanalysis (SG, protein, urinary sediment), and ultrasound of the kidneys. We evaluated the surgical wound healing daily. In addition, we also evaluated the presence of oedema, erythema, secernation and pain of the wound. The sutures were removed on the tenth day after the surgery.

\section{Statistical evaluation}

The onset of post-surgical complications was compared according to different surgical procedures on the neck (SLOT) and on the thoracolumbar spine. In addition, the relationship between observed complications and different types of application of the contrast medium (cranial, caudal, both types in one) was closely evaluated. For the evaluation we used Student's $t$-test or Fisher's test. The level of significance was considered $p<0.05$ for significant variations and $p<0.01$ for highly significant variations.

\section{Results}

We did not find any difference in either perianaesthetic variables or in the duration of anaesthesia. Comparing cranial with caudal myelography, we observed seizures more frequently after cranial myelography $(p<0.05)$ (Table 1). Gastrointestinal complications were more frequently observed after surgery on the thoracolumbar spine in patients with Grade IV of neurological signs when compared with the patients that had undergone the same type of surgical procedure with Grades I - III of neurological signs (Table 3). Comparing all different complications with each other, we found that surgical procedures on the neck (SLOT) resulted in death of the animal more frequently $(p<0.05)$ than in patients with surgery on the thoracolumbar spine (hemilaminectomy) (Table 5). In the rest of the cases, no significant difference among the groups was observed (Tables 2 and 4).

\section{Discussion}

In our group of patients we observed a higher incidence of seizures after cranial myelography compared to caudal myelography. This phenomenon might be due to a slowed-down flow of the contrast medium caudally (Barber et al. 1987) and its neurotoxic effect (Barone et al. 2002), or the contrast medium might enter the cerebellomedullar 
Table 1. The onset of seizures in connection with the type of myelography

\begin{tabular}{|l|c|c|c|}
\hline \multicolumn{1}{|c|}{ Type of myelography } & Cranial & Caudal & Cranial and caudal \\
\hline Seizures & 8 & 14 & 1 \\
\hline No seizures & 23 & 111 & 4 \\
\hline
\end{tabular}

$* p<0.05$

Table 2. GI complications with SLOT due to the degree of neurological deficits

\begin{tabular}{|c|c|c|}
\hline Degree & Patients with complications & Total number of patients \\
\hline II & 0 & 5 \\
\hline III & 1 & 13 \\
\hline
\end{tabular}

Table 3. GI complications with hemilaminectomy due to the degree of neurological deficits

\begin{tabular}{|c|c|c|}
\hline Degree & Patients with complications & Total number of patients \\
\hline I & 0 & 1 \\
\hline II & 0 & 7 \\
\hline III & 4 & 29 \\
\hline IV & $24 *$ & 106 \\
\hline
\end{tabular}

$* p<0.05$

Table 4. The onset of cystitis due to the lesion localization and the degree of neurological deficits

\begin{tabular}{|l|c|c|}
\hline \multicolumn{1}{|c|}{ Type of deficit } & Patients with complications & Total number of patients \\
\hline SLOT & 0 & 18 \\
\hline Hemilaminectomy - I & 0 & 1 \\
\hline Hemilaminectomy - II & 0 & 7 \\
\hline Hemilaminectomy - III & 1 & 29 \\
\hline Hemilaminectomy - IV & 8 & 106 \\
\hline
\end{tabular}

Table 5. The onset of all types of complications due to the lesion site

\begin{tabular}{|l|c|c|}
\hline Complication & SLOT & Hemilaminectomy \\
\hline Seizure & 4 & 19 \\
\hline GI signs & 1 & 28 \\
\hline Cystitis & 0 & 9 \\
\hline Haemorrhage & 0 & 2 \\
\hline Surgical wound infection & 0 & 2 \\
\hline Death & $2^{*}$ & 1 \\
\hline Total number of patients & 18 & 143 \\
\hline
\end{tabular}

$* p<0.05$

cistern (Adams and Stowater 1981). The risk of seizures appears to be lower if the surgery follows immediately (meanwhile the contrast medium is excreted from the organism) (Widmer et al. 1992). Some authors (Roberts and Selcer 1993) describe the influence of anaesthetic combination on the onset of seizures. We can rule out both the duration of anaesthesia and the combination of anaesthetics in our group of animals (decrease of the threshold for the onset of seizures, affection of intracranial pressure). Medetomidin (the drug we used) decreases blood perfusion in the brain and thus also the intracranial pressure is lowered (Keegan et al. 1995); propofol, same as barbiturates, reduces epileptic activity. Accordingly, these drugs are suitable as anaesthetic agents while performing myelography. Propofol can also be used as an anticolvulsive agent (Harvey et al. 1996; Reid and Nolan 1999). We maintained adequate hydration using fluid therapy, thus eliminating the negative 
impact of dehydration on the contrast medium resorption from the spinal canal (Roberts and Selcer 1993).

When we observed seizures in a patient, we gave diazepam intravenously at the dose of $0.2-0.4 \mathrm{mg} / \mathrm{kg}$. Placing the patient on a slant pad in a quiet room with the head kept up and with adequate fluid therapy may be beneficial for stimulating the contrast medium flow caudally, its early excretion from the organism, and reducing the risk of seizures (Roberts and Selcer 1993).

During the decompression procedures it is recommended to give steroids intravenously, as it might have a beneficial effect on reducing the damage during surgical procedures in the spine region (Toombs and Bauer 1993), however, the risk of GI ulcerations and erosions has been described in connection with steroid application (Anderson et al. 1992; Behrend and Kemppainen 1997; Rohrer et al. 1999). These erosions or even ulcerations occur not only in the stomach and duodenum (Anderson et al. 1992; Behrend and Kemppainen 1997; Hart et al. 1997b; Rohrer et al. 1999), but these lesions appear to be much more dangerous in the descendent colon (Toombs et al. 1980, 1986). In patients with an intervertebral disc disease, local irritation of the intestinal wall and faecal stasis in the colon due to an increased tone of the sympathicus can be observed. These patients are predisposed to obstipation and colon ulceration (Toombs et al. 1980). The application of steroids may worsen the situation due to reducing mucus production (Menguy and Masters 1963) and slowed-down cell regeneration, which may lead to intestinal perforation, particularly in the descendent colon (Toombs et al. 1980). As a consequence, peritonitis, sepsis, and eventually death may occur (Toombs et al. 1980, 1986).

The higher risk of the onset of ulcerations and colon perforation was observed in male paraplegic patients treated with dexamethasone (Toombs et al. 1986). Methylprednisolon sodium succinate was given perioperatively to patients included in the study. This drug is thought to cause less GI complications compared with dexamethasone (Culbert et al. 1998). Nevertheless, we found a significantly higher incidence of GI complications in paraplegic patients.

If steroids and NSAIDs are given simultaneously, there is a higher risk of GI toxicity caused by NSAIDs (Dow et al. 1990). This might lead to the onset of gastric and colonic perforation (Amsellem et al. 2003). It must be emphasized that $\mathrm{H}_{2}$ receptor blockers given as prevention for GI ulceration do not have the same effect when steroids are administered (Rohrer et al. 1999). Even the application of misoprostol does not appear to have preventive antiulcerogenic effect when steroids are given (Rohrer et al. 1999; Toombs and Bauer 1993). Sucralfate provides a protective effect (Anderson et al. 1992).

In the study by Moore and Withrow (1982), 23 of 155 dogs with intervertebral disc disease were presented with GI complications after the administration of steroids. The combination of neurological disease and administration of steroids may result in GI ulceration (Moore and Withrow 1982).

Micturition disorders are usually presented in patients with the degree III and IV of neurological deficits (Toombs and Bauer 1993). Inadequate emptying of the urinary bladder may lead to cystitis, pyelonephritis or iatrogenic rupture of the urinary bladder (Hart et al. 1997a). Cystitis may be avoided by a complete emptying of the urinary bladder (Amsellem et al. 2003); for this reason we manually emptied the urinary bladder in our patients 3 - 4 times a day (Amsellem et al. 2003; Toombs and Bauer 1993). The occurrence of cystitis was not significant in our study.

Manual emptying of the urinary bladder is generally preferred to catheterisation, because there is a lesser risk of iatrogenic infection (Amsellem et al. 2003; Oliver et al. 1987). The role of manual bladder emptying in the onset of colon perforation must yet be explored (Toombs et al. 1986).

The emptying of the urinary bladder can be eased by administration of a number of agents. 
Phenoxybenzamine (alfa-adrenergic receptors blockers) at the dose of $0.25-0.5 \mathrm{mg} / \mathrm{kg}$ once a day per os decreases the tone of smooth muscle in the proximal urethra (Amsellem et al. 2003). Diazepam at the dose of $0.2-1 \mathrm{mg} / \mathrm{kg}$ three times a day per os may be administered simultaneously with phenoxybenzamine to decrease the tone of the external urethral sphincter (Amsellem et al. 2003). In patients with detrusor atony, the combination of phenoxybenzamine (at the dose of $0.5 \mathrm{mg} / \mathrm{kg}$ ) once a day and betanechol (at the dose of 5 - $15 \mathrm{mg}$ per animal) three times a day per os (Amsellem et al. 2003). Phenoxybenzamine and betanechol are not recommended for animals with a cardiovascular disease. Betanechol should not be used in patients with urinary tract obstruction (Amsellem et al. 2003).

Intermittent catheterisation appears to be a better choice, since there is a reduced risk of iatrogenic urinary tract infection (Amsellem et al. 2003). When catheterisation is performed for more than 4 days, it is always recommended to submit the urine for culture and urinoanalysis (Hart et al. 1997a).

Repeated urinoanalysis enables to detect infection and initiate therapy as soon as possible (Oliver et al. 1987). In dogs with the intervertebral disc disease the signs of cystitis (pollakiuria, dysuria) are not always obvious. Haematuria is usually the only finding (Hart et al. 1997a). We detected cystitis in our patients using repeated urinoanalysis.

The choice of an antibiotic drug should be based on the antibiogram (Hart et al. 1997a). The antibiotic should easily penetrate the prostatic tissue in male dogs (Senior 1998).

In animals with rear limbs paralysis, repeated urine culture every one to two months is strongly recommended (Hart et al. 1997a).

Complications of surgical wound healing were described in $14 \%$ of patients after surgery. Seroma occurs in approximately $10 \%$ of patients after spine surgery in the thoracolumbar region. The most frequent healing complication in such patients is oedema. Heat appeared to have a positive effect on oedema resorption, pain alleviation and muscle spasm relief within 48 - $72 \mathrm{~h}$ after surgery (Hart et al. 1997a).

The least frequent complication after surgery is partial or complete wound dehiscence (Hart et al. 1997b). We confirmed this finding as we did not observe a significant incidence of wound healing complication.

Postoperative infection was documented in $2.5 \%$ of "clean" surgical procedures, where neurosurgery is included (Remedios 1999; Vasseur 1988). The incidence of wound infection was estimated not to exceed $3.5 \%$ in patients with spine surgery (Hart et al. $1997 b$ ). Fever is not a reliable marker of infection, as many patients have a fever due to inflammatory mediators release after surgery. Fever without infection lasts for only 1 3 days. Dehiscence may occur due to wound infection (Hart et al. 1997b). The dorsal approach which is widely used for thoracolumbar and lumbar spine surgeries does not provide adequate wound drainage and may predispose for deep infection of the surgical wound (Hart et al. 1997b). In our study the surgical wound was infected only after hemilaminectomy, but the frequency of the complication was not significant.

Apparently, bacterial contamination and infections occur significantly more often in procedures that take longer than 90 - 120 min (Hart et al. 1997b).

Antibiotic treatment as a preventive measure for infection is required when the surgery takes longer than 90 min (Vasseur 1988).

Anaesthetic complication is one of the reasons of the animal's death. During the application of the contrast medium and consequent placing of the animal into the right recumbency, the respiratory and heart rate may be altered (Evans 1996; Harvey et al. 1996). Cardiac dysfunctions are most common in decompressive surgeries on the neck and thoracolumbar spine (Coates 2000). In our study we did not observe any respiratory and cardiovascular abnormalities during myelography and surgeries.

We found that patient death appeared to be more frequent with SLOT compared to hemilaminectomy. These patients are predisposed to accumulation of bronchial secrets 
and atelectases in the ventral part of the lungs. They are also exposed to a higher risk of bacterial pneumonia and death. An effective preventive measure seems to be the regular turning of the animals every 2 - 4 h (Hart et al. 1997b). Progressive myelomalacia may also cause death. This condition causes tetraplegia and eventually death due to respiratory paralysis (Oliver et al. 1987).

In patients that die within the $3^{\text {rd }}$ to $5^{\text {th }}$ day after the surgical procedure on the spine for the intervertebral disk disease, the cause of death is generally ascribed to descendent colon perforation and consequent septic peritonitis and sepsis, particularly in patients with paraplegia (Toombs et al. 1980, 1986). In our study we observed patient death once after hemilaminectomy, which was non-significant.

Based on the results of our study, we may conclude that GI complications appeared to be more frequent in patients with an intervertebral disk disease sited on thoracolumbar spine, particularly in patients with paraplegia. Cranial myelography appeared to be more risky as for the onset of seizures during recovery from anaesthesia. SLOT appears to be a more dangerous procedure compared with hemilaminectomy, as it may cause death of the patients.

\section{Komplikace související s chirurgickou léčbou onemocnění meziobratlové ploténky u psů}

Po chirurgickém ošetření onemocnění meziobratlové ploténky se setkáváme s celou řadou komplikací (křeče, ulcerace GIT, cystitidy a komplikace v hojení operační rány), které mohou vést až k úhynu. U 161 psů s onemocněním meziobratlové ploténky jsme provedli klinické a laboratorní vyšetření. Následně u nich byla v celkové anestézii provedena kraniální $(\mathrm{n}=31)$, kaudální $(\mathrm{n}=125)$, př́ipadně oba typy myelografie současně $(\mathrm{n}=5)$ a chirurgický zákrok - SLOT $(\mathrm{n}=18)$, hemilaminektomie $(\mathrm{n}=143)$. V pooperačním období jsme zaznamenávali výskyt křečí, GIT komplikací, cystitidy, komplikací v hojení operační rány a úhyn pacientů ve vztahu $\mathrm{k}$ lokalizaci, stupni postižení a typu chirurgického zákroku. V naší studii jsme zaznamenali vyšší výskyt kř̌ečí po kraniální myelografii, častější výskyt GIT komplikací při lokalizaci IVDD v torakolumbálním úseku páteře, zvláště u paraplegických psů a častější úhyn u pacientů po SLOT. Výskyt cystitidy nebyl statisticky významný. Z naší studie vyplývá, že nejčastějšími komplikacemi jsou křeče, ulcerace GIT a úhyn, jejichž zastoupení se liší dle lokalizace a stupně neurologického postižení.

\section{References}

ADAMS WM, STOWATER JL 1981: Complications of metrizamide myelography in the dog: A summary of 107 clinical case histories. Vet Radiol 22: 27-34

AMSELLEM PM, TOOMBS JP, LAVERTY PH, BREUR GJ 2003: Loss of deep pain sensation following thoracolumbar intervertebral disk herniation in dogs: Treatment and prognosis. Compend Cont Educ Pract Vet 25: $266-273$

ANDERSON NV, SHERDING RG, MERRITT AM, WHITLOCK R (Eds.)1992: Veterinary gastroenterology, $2^{\text {nd }}$ ed. Lea \& Febiger, Philadelphia; 873 p.

BARBER DL, OLIVER JE, MAYHEW IG 1987: Neuroradiography. In: OLIVER JE, HOERLEIN BF, MAYHEW IG: Veterinary Neurology. W. B. Saunders, Philadelphia, pp. 65-110

BARONE G, ZIEMER LS, SHOFER FS, STEINBERG SA, 2002: Risk factors associated with development of seizures after use of iohexol for myelography in dogs: 182 cases (1998). J Am Vet Med Assoc 10: 1499-1502

BAUER M, GLICKMAN N, GLICKMAN L, TOOMBS J, GOLDEN S, SKOWRONEK C 1992: Follow-up study of owner attitudes toward home care of paraplegic dogs. J Am Vet Med Assoc 200: 1809-1816

BEHREND EN, KEMPPAINEN RJ 1997: Glucocorticoid therapy: Pharmacology, indications, and complications. Vet Clin N-Am Small Anim Pract 27: 187-213

COATES JR 2000: Intervertebral disk disease. Vet Clin N-Am Small Anim Pract 1: 77-110

CULBERT LA, MARINO DJ, BAULE RM, KNOX VW 1998: Complications associated with high-dose prednisolone sodium succinate therapy in dogs with neurological injury. J Am Anim Hosp Assoc 34: 129-34

DENNIS R 1987: Radiographic examination of the canine spine. Vet Rec 121: 31-35

DOW SW, ROSYCHUK RA, McCHESNEY AE, CURTIS CR 1990: Effect of flunixin and flunixin plus prednisone on the gastrointestinal tract of dogs. Am J Vet Res 51: 1131-1138 
EVANS AT 1996: Anaesthetic emergencies and accidents. In: THURMON JC, TRANQUILLI WJ, BENSON GJ (Eds.): Lumb \& Jones' Veterinary Anaesthesia. $3^{\text {rd }}$ ed. Williams \& Wilkins, Baltimore, pp. 849-860

HART RC, JERRAM RM, SCHULZ KS 1997a: Postoperative management of the canine spinal surgery patient - Part I. Compend Contin Educ Pract Vet 19: 1147-1161

HART RC, JERRAM RM, SCHULZ KS 1997b: Postoperative management of canine spinal surgery patient - Part II. Compend Contin Educ Pract Vet 19: 1133-1146

HARVEY RC, SIMS MH, GREENE SA 1996: Neurologic disease. In THURMON JC, TRANQUILLI WJ, BENSON GJ: Lumb \& Jones' Veterinary Anaesthesia. $3^{\text {rd }}$ ed., Williams \& Wilkins, Baltimore, pp. 775-785

KEEGAN RD, GREENE SA, BAGLEY RS, MOORE MP, WEIL AB, SHORT CE 1995: Effects of medetomidine administration on intracranial pressure and cardiovascular variables of isoflurane-anesthetized dogs. Am J Vet Res 56: 193-198

MENGUY R, MASTERS YF 1963: Effect of cortisone on mucoprotein secretion by gastric antrum of dogs: Pathogenesis of steroid ulcer. Surgery 54: 19-28

MOORE RW, WITHROW SJ 1982: Gastrointestinal haemorrhage and pancreatitis associated with intervertebral disc disease in the dog. J Am Vet Med Assoc 180: 1443-1447

NEČAS A 1999: Clinical aspects of surgical treatment of thoracolumbar disc disease in dogs. A retrospective study of 300 cases. Acta Vet Brno 68: 121-130

NEČAS A 2000: Rate of Neurologic Recovery as an indicator of long-term prognosis in dogs with surgically treated thoracolumbar disc disease. Vet Med-Czech 45: 19-24

NEČAS A, SEDLÁKOVÁ D 1999: Changes in the creatine kinase and lactate dehydrogenase activities in cerebrospinal fluid of dogs with thoracolumbar disc disease. Acta Vet Brno 68: 111-120

OLIVER JE, HOERLEIN BF, MAYHEW IG 1987: Veterinary neurology. W.B. Saunders, Philadelphia; 544 p.

REID J, NOLAN AM 1999: Intravenous Anaesthetics. In: SEYMOUR CH, GLEED R (Eds.): Manual of small animal anaesthesia and analgesia, BSAVA, Shurdington, pp. 88-95

REMEDIOS A 1999: Complications of wound healing. In: FOWLER D, WILLIAMS JM: Manual of Canine and Feline Wound Management and Reconstruction, BSAVA, Shurdington, Cheltenham, pp. 137-143

ROBERTS RE, SELCER BA 1993: Myelography and epidurography. Vet Clin N Am-Small Anim Pract 23: 307-329

ROHRER CR, HILL RC, FISCHER A, FOX LE, SCHAER M, GINN PE, PREAST VA, BURROWS CF 1999: Efficacy of misoprostol in prevention of gastric haemorrhage in dogs treated with high doses of methylprednisolone sodium succinate, Am J Vet Res 60: 982-985

SANDE RD 1992: Radiography, myelography, computed tomography, and magnetic resonance imaging of the spine. Vet Clin N Am-Small Anim Pract 22: 811-831

SENIOR DF 1998: Glomerulonephropathy. In: Sborník ze semináře: Nephrourology and prostatic diseases in small animals. WSAVA Meeting, Praha; pp. 10-14

TOOMBS JP, BAUER MS 1993: Intervertebral disc disease. In: SLATTER D: Textbook of small animal surgery. $2^{\text {nd }}$ ed. W. B. Saunders, Philadelphia, pp. 1070-1087

TOOMBS JP, CAYWOOD DD, LIPOWITZ AJ, STEVENS JB 1980: Colonic perforation following neurosurgical procedures and corticosteroid therapy in four dogs. J Am Vet Med Assoc 177: 68-72

TOOMBS JP, COLLINS LG, GRAVES GM, CROWE DT, CAYWOOD DD 1986: Colonic perforation in corticosteroid-treated dogs. J Am Vet Med Assoc 188: 145-150

VASSEUR PB 1988: Surgical wound infection rates in dogs and cats. Data from a teaching hospital. Vet Surg 17: $60-64$

WIDMER WR, BLEVINS WE, JAKOVLJEVIC S, TECLAW RF, HANN CM, HURD CD 1992: Iohexol and iopamidol myelography in the dog: A clinical trial comparing adverse effects and myelographic quality. Vet Radiol 33: 327-333

WRIGHT JA, CLAYTON JDG 1981: Metrizamide myelography in sixty-eight dogs. J Small Anim Pract 22: 415-435 